\title{
Role of Impulsivity, Aggression in Alcohol Dependence - A Cross Sectional Study from Vellore, India
}

\author{
Pichaachari Rathika1 ${ }^{1}$, Kaliyan Veeramuthu ${ }^{2}$, Arumugam Subramanian Senthilkumar ${ }^{3}$
}

1, 2, 3 Department of Psychiatry, Government Vellore Medical College and Hospital, Vellore, Tamil Nadu, India

\section{ABSTRACT}

\section{BACKGROUND}

Alcohol use disorder is one of the dangerous public health burden. The construct of impulsivity and its various dimensions in relation with aggression are relevant for understanding alcohol dependence and relapse. The goal of the study is to describe the role of impulsivity and aggression in the context of alcohol dependence. The purpose and implications of this study was to understand the human factors contributing to aggression and impulsivity and in providing advanced treatment programs.

\section{METHODS}

This cross-sectional study was discussed in detail and approved by the ethical committee of the Madras Medical College. The cases were selected consecutively from all the patients attending the outpatients as well as inpatient for the same after fulfilling the inclusion and exclusion criteria, within seven days of last intake of alcohol. The diagnosis was made according to International Classification of Diseases (ICD-10) criteria after ruling out psychotic disorder and other comorbid medical illnesses. Informed consent was obtained from all the patients and caregivers. Descriptive statistics used meticulously to measure the magnitude.

\section{RESULTS}

This study found significant positive correlation $(\mathrm{P}<0.001)$ between impulsivity, aggression subtypes with alcohol dependence. Various subsets in Barrett impulsivity scale (BIS) and subsets of Buss Perry aggression scales (BPAS) had positive correlations. We found that as severity of dependence increases, impulsivity and aggression scores increases and vice versa. The comparison of means of illness variables within groups showed that there was no significant difference between groups in terms of age of onset of illness, last alcohol intake, number of hospital admissions, duration of abstinence and frequency of relapse.

\section{CONCLUSIONS}

This study describes the important role of behavioural model and disease model of alcoholism,1,2 greatly stresses the inability to control the quantity and frequency of the drinking behaviour. There is higher level of connectivity between alcohol dependence with biological and behavioural indicators of impulsivity and aggression. ${ }^{3}$ It supports that relapse is an acquired behaviour in which the individual is able to control his substance taking pattern through adequate cognitive behavioural techniques in addition to pharmacological treatment and also suggest more research needed in future to focus on causality and intervention.
Corresponding Author:

Dr. Arumugam Subramanian Senthilkumar, 33B, C/O K.Indumathy, Kamala Avenue,

AVP Azhagammal Nagar,

Near New Bus Stand, Thanjavur-5,

Tamil Nadu, India.

E-mail: redcholan@gmail.com

DOI: $10.14260 /$ jemds/2021/714

How to Cite This Article:

Rathika P, Veeramuthu K, Senthilkumar AS

Role of impulsivity, aggression in alcohol dependence - a cross sectional study from Vellore, India. J Evolution Med Dent Sci 2021;10(40):3520-3525,

$10.14260 /$ jemds/2021/714

Submission 28-06-2021,

Peer Review 25-08-2021,

Acceptance 31-08-2021,

Published 04-10-2021.

Copyright (C) 2021 Pichaachari Rathika et al. This is an open access article distributed under Creative Commons Attribution License [Attribution 4.0 International (CC BY 4.0)]

\section{KEY WORDS}

Impulsivity, Aggression, Alcohol dependence, Relapse 


\section{BACKGROUND}

Substance use is increasing in India and is being reported as a growing burden in both urban and rural areas. The epidemiological studies carried out over time in different parts of our country indicate an escalating trend. Alcohol is the major substance used across the country, and violence and suicides ${ }^{4}$ in alcohol use disorder individuals are emerging as important public health concern in many states and territories of India.5,6,7 Impulsive behaviour in alcoholics puts them at serious risk of severe course of disease and has been related to the serotonergic neurotransmission dysfunction ${ }^{8}$. The aim of this study is to investigate the association between various subtypes of impulsivity dimension with aggression dimension in relation to alcohol dependence.

Why does not everyone who takes alcohol once get addicted to it? Some drugs seem to involve with vulnerability, and are intrinsically more addictive than others. ${ }^{9}$ Another reason is that some individuals may be more impulsive by nature. Alcohol dependence is often associated with impulsivity, which may be correlated with dysfunction of the brain reward system. ${ }^{10}$ Detoxified alcoholics showed reduced activation of the ventral striatum during anticipation of monetary gain relative to healthy subjects. Few studies suggest that reduced ventral striatal recruitment during anticipation of conventional rewards in alcoholics may be related to their increased impulsivity, and indicate possibilities for enhanced treatment approaches in alcohol dependence. ${ }^{11}$

Impulsivity is defined as acting without forethought, with lack of concern about the consequence of one's own behaviour, ${ }^{12}$ inability to control, and lack of willpower to give up his or her temptation. Impulsivity coming as an adverse consequence of lesions in ventral striatum will acquire compulsive drinking habit. Other areas responsible include dorsal striatum and different parts of the prefrontal cortex. Aggression is a complex human behaviour and experience (not provoking violence), wherein the amygdala and the hypothalamus are the anatomical areas involved along with the neural network responsible to regulate negative affect.

Environmental factors and genetically dysfunctional reward system also play a role. ${ }^{13}$ It will trigger neuroplasticity in the compulsory circuit resulting in dependence in some individuals. Impulsivity is related to low 5-HT level,14,15 and subsequent loss of impulse control due to impaired inhibition effect of frontal cortex especially in adolescence, and to neurodevelopmental processes and reproductive hormones in late adolescence. Aggression is defined as behaviour intended to harm oneself and/or others. Several evidences suggest that alcohol intoxication lowers the threshold for aggression. Low expression of MAOA gene increases the risk of aggression. Impulsivity is an important correlate of risky behaviours in alcohol-dependent individuals, along with global psychopathology and severity of alcohol dependence.16. We examined neural correlates potentially moderating the relationship between human aggressive behaviour and chronic alcohol use. ${ }^{17}$

Various factors such as biological, social and psychological predict alcohol dependence and relapse. ${ }^{18}$ Higher frequency of alcohol consuming behaviour (i.e. more than four times a week) is generally found in older population whereas higher intake on single occasion is commonly seen in younger population. ${ }^{19}$

Alcohol dependence is considered as a biopsychosocial problem involving many individual and environmental risk factors.

About $70-90 \%$ of the persons suffering from alcohol dependence syndrome relapse within three months. ${ }^{20}$ Various cognitive, personality ${ }^{21}$ and situational factors have been found to be related to impulsivity and aggression. Previous research had suggested a potential role for deficits in social problem-solving skills as a 'mediator' between impulsivity and aggression. ${ }^{22}$

Additionally, it is well established that aggression and impulsivity are more likely to occur in the context of alcohol use, ${ }^{23,24}$ based on which a model of aggression was developed involving impulsivity and alcohol dependency. The purpose of this study is to understand about the role of impulsivity and aggression (human factors) contributing to alcohol dependence and implications for further enhancement of treatment programs.

\section{METHODS}

This cross-sectional study was approved by the Institutional Ethical Committee of Madras Medical College, Institute of Mental Health, Chennai over a period of 3 months from March 2017 to May 2017. A total of 100 individuals with alcohol dependence, were selected consecutively from all the patients attending the outpatient department as well as inpatient ward, after fulfilling the inclusion and exclusion criteria, with a history of abstinence recently, and relapse within the past seven days. The diagnosis was made according to ICD-10 criteria after ruling out psychotic disorder and other comorbid medical illnesses. Informed consent was obtained from all the patients and their caregivers.

\section{Inclusion Criteria}

1. Subjects fulfilling ICD-10 criteria for alcohol dependence, with relapse in the past seven days

2. Age $20-60$ years

3. Those who are cognitively able to give written consent to participate in the study

\section{Exclusion Criteria}

1. Other axis-I disorders

2. Other substance use except nicotine

3. Individuals with comorbid medical and neurological conditions

4. Those who are not willing to give written consent to participate in the study

\section{Instruments Used}

1. Semi-structured socio demographic proforma

2. Alcohol use disorder identification test (AUDIT)

3. Barratt impulsiveness scales (BIS -11)

4. Buss Perry aggression questionnaire (BPAQ)

5. Severity of alcohol dependence questionnaire (SADQ) 


\section{RESULTS}

The sample consist of 100 patients $(\mathrm{N}=100)$. A semistructured proforma was used to collect patients' details. In this study, individuals in the age group of 20 - 60 years who consumed alcohol regularly were enrolled. Majority of alcohol users were in the middle age group, with predominantly lower levels of education. Most were unskilled (31\%), semiskilled (30\%), unemployed (23\%) workers. Majority were married and have an income less than INR 7600 (66\%) per month. Their drinking patterns revealed that nearly three fourth of the men have been using alcohol for more than five years.

\section{Distribution of Habitat}

As the study was conducted in a tertiary care center in Chennai, majority of the participants were from urban setting. Tamil is the leading language in our state and $91 \%$ of the participants were Tamil-speaking. About $82 \%$ of the study group belonged to Hinduism; $74 \%$ were living in joint family, $26 \%$ in nuclear family; $75 \%$ of the study population had a family history of alcoholism. The analysis of the duration of abstinence maintained by the patients shows that nearly $40 \%$ of our sample relapsed to drinking alcohol within three months duration.

The mean score of impulsivity in various subscales like attention, motor and planning were 18.05, 24.82 and 24.22 respectively (table - 1). It is also shown that the mean score of severity of alcohol dependence in our sample was 32.31 with a standard deviation of 15.885 . Table - 2 shows that as the severity of alcohol dependence increases, impulsivity score increases. Similarly, as every subscale of impulsivity increases, other domain scores also increase.

The comparison shows differences between impulsivity subtype means score and aggression subtype means score (table - 3) being statistically significant, which implies a change in one variable alters another variable significantly. Table - 4 shows that the mean age of presentation was 39.12 years with standard deviation 7.891 years. The age of onset of illness was 21.52 years with standard deviation of 5.436 years. The average duration of abstinence was 3.18 months with standard deviation of 4.101 .

Impulsivity and aggression were positively correlated with severity of dependence (table - 5). The mean score of aggression subsets -- physical, verbal, anger and hostility, were comparable with SADQ scores (table - 6).

Among aggression (AGG) sub facets, except hostility all other variables positively correlated with SADQ scores (table 7). There was no significant difference between groups (table - 8) in terms of age of onset of illness, last alcohol intake, number of hospital admissions, duration of abstinence and frequency of relapse.

The present study explains how impulsivity and aggression were positively correlated with severity of alcohol dependence and vice versa. In this study, among the impulsivity subset variables, motor and planning have high means score compared to attentional facet, without any change in significant correlation of total impulsivity with SADQ score.

In aggression subsets, the domain of physical aggression had a high mean score, compared to other domains; except hostility all other were significantly comparable with SADQ scores. However, the total score did not have any difference with significance.

\begin{tabular}{|cccc|}
\hline & Mean & Standard Deviation & N \\
Bar attention & 18.05 & 5.515 & 100 \\
Bar motor & 24.82 & 7.234 & 100 \\
Bar planning & 24.22 & 7.236 & 100 \\
SADQ & 32.31 & 15.885 & 100 \\
\hline \multicolumn{4}{c}{ Table 1. Descriptive Statistics } \\
\hline
\end{tabular}

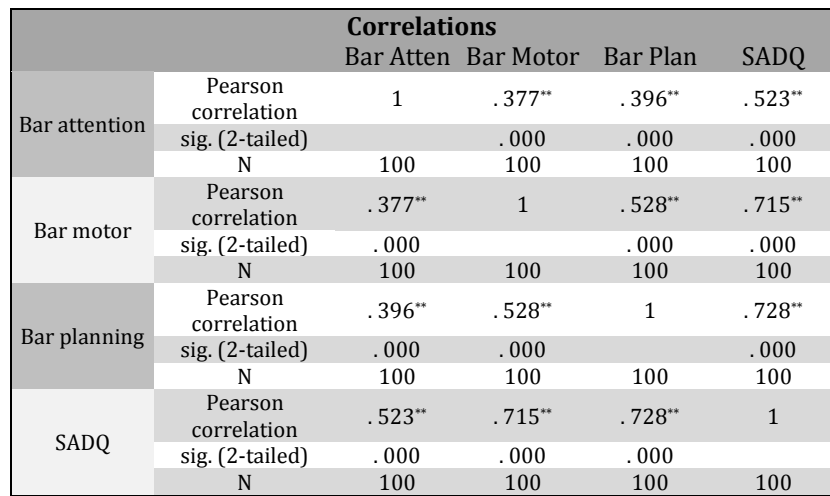

Table 2. Pearson Correlation between Impulsivity Scores and Severity of Alcohol Dependence

\begin{tabular}{|c|c|c|c|c|c|c|}
\hline & & $\begin{array}{l}\text { Sum of } \\
\text { Squares }\end{array}$ & df & $\begin{array}{c}\text { Mean } \\
\text { Square }\end{array}$ & $\mathbf{F}$ & Sig. \\
\hline \multirow{3}{*}{$\begin{array}{c}\text { Bar } \\
\text { attention }\end{array}$} & Between groups & 962.389 & 2 & 481. 195 & 22.787 & .000 \\
\hline & Within groups & 2048. 361 & 97 & 21.117 & & \\
\hline & Total & 3010.750 & 99 & & & \\
\hline \multirow{3}{*}{$\begin{array}{l}\text { Bar } \\
\text { motor }\end{array}$} & Between groups & 2203. 961 & 2 & 1101.980 & 35.908 & .000 \\
\hline & Within groups & 2976. 799 & 97 & 30.689 & & \\
\hline & Total & 5180.760 & 99 & & & \\
\hline \multirow{3}{*}{$\begin{array}{c}\text { Bar } \\
\text { planning }\end{array}$} & Between groups & 2682. 390 & 2 & 1341. 195 & 52.022 & .000 \\
\hline & Within groups & 2500.770 & 97 & 25.781 & & \\
\hline & Total & 5183. 160 & 99 & & & \\
\hline \multirow{3}{*}{$\begin{array}{l}\text { AGG } \\
\text { physical }\end{array}$} & Between groups & 753.932 & 2 & 376.966 & 12.704 & .000 \\
\hline & Within groups & 2878. 178 & 97 & 29.672 & & \\
\hline & Total & 3632.110 & 99 & & & \\
\hline \multirow{3}{*}{$\begin{array}{c}\text { AGG } \\
\text { verbal }\end{array}$} & Between groups & 321.433 & 2 & 160.716 & 9.162 & .000 \\
\hline & Within groups & 1701. 557 & 97 & 17.542 & & \\
\hline & Total & 2022.990 & 99 & & & \\
\hline \multirow{3}{*}{ Anger } & Between groups & 382.643 & 2 & 191. 321 & 11.978 & .000 \\
\hline & Within groups & 1549.317 & 97 & 15.972 & & \\
\hline & Total & 1931.960 & 99 & & & \\
\hline \multirow{3}{*}{ Hostility } & Between groups & 311.484 & 2 & 155.742 & 8. 277 & .000 \\
\hline & Within groups & 1825.106 & 97 & 18.816 & & \\
\hline & Total & 2136.590 & 99 & & & \\
\hline \multicolumn{7}{|c|}{ Table 3. ANOVA } \\
\hline
\end{tabular}

\begin{tabular}{|c|c|c|c|c|c|}
\hline & & Age & $\begin{array}{c}\text { Age of Onset } \\
\text { of Illness }\end{array}$ & Last Intake & $\begin{array}{c}\text { Abstinence } \\
\text { Duration }\end{array}$ \\
\hline \multicolumn{2}{|l|}{$\mathrm{N}$} & 100 & 100 & 100 & 100 \\
\hline \multicolumn{2}{|c|}{ Mean } & 39.12 & 21.52 & 3. 29 & 3. 18 \\
\hline \multicolumn{2}{|c|}{ Median } & 39.00 & 20.00 & 3. 00 & 2. 00 \\
\hline \multicolumn{2}{|c|}{ Standard deviation } & 7.891 & 5. 436 & 1.816 & 4. 101 \\
\hline \multirow{3}{*}{ Percentiles } & 25 & 34.00 & 18.00 & 2. 00 & 1.00 \\
\hline & 50 & 39.00 & 20.00 & 3. 00 & 2. 00 \\
\hline & 75 & 45. 00 & 25.00 & 5. 00 & 4. 00 \\
\hline \multicolumn{6}{|c|}{ Table 4. Descriptive Statistics } \\
\hline
\end{tabular}

\begin{tabular}{|c|c|c|c|c|c|}
\hline & & SADQ & Audit & $\begin{array}{c}\text { Total } \\
\text { Aggression }\end{array}$ & $\begin{array}{c}\text { Total } \\
\text { Impulsivity }\end{array}$ \\
\hline \multirow{3}{*}{ SADQ } & $\begin{array}{l}\text { Pearson } \\
\text { correlation }\end{array}$ & 1 & .009 & $.597^{* *}$ & $.844^{* *}$ \\
\hline & sig. (2-tailed) & & .932 & .000 & .000 \\
\hline & $\mathrm{N}$ & 100 & 100 & 100 & 100 \\
\hline \multirow{3}{*}{ AUDIT } & $\begin{array}{l}\text { Pearson } \\
\text { correlation }\end{array}$ & .009 & 1 & .034 & .071 \\
\hline & sig. (2-tailed) & .932 & & .735 & 482 \\
\hline & $\mathrm{N}$ & 100 & 100 & 100 & 100 \\
\hline \multirow{3}{*}{$\begin{array}{c}\text { Total } \\
\text { aggression }\end{array}$} & $\begin{array}{l}\text { Pearson } \\
\text { correlation }\end{array}$ & $597^{*-}$ & .034 & 1 & $692^{* *}$ \\
\hline & sig. (2-tailed) & .000 & .735 & & .000 \\
\hline & $\mathrm{N}$ & 100 & 100 & 100 & 100 \\
\hline \multirow{3}{*}{$\begin{array}{c}\text { Total } \\
\text { impulsivity }\end{array}$} & $\begin{array}{l}\text { Pearson } \\
\text { correlation }\end{array}$ & $844^{*-}$ & 071 & $.692^{* *}$ & 1 \\
\hline & sig. (2-tailed) & .000 & 482 & .000 & \\
\hline & $\mathrm{N}$ & 100 & 100 & 100 & 100 \\
\hline \multicolumn{6}{|c|}{ Table 5. Correlations } \\
\hline
\end{tabular}




\begin{tabular}{|c|ccc|}
\hline & Mean & Stdandard Deviation & N \\
\hline SADQ & 32.31 & 15.885 & 100 \\
AGG physical & 21.33 & 6.057 & 100 \\
AGG verbal & 11.51 & 4.520 & 100 \\
Anger & 14.02 & 4.418 & 100 \\
Hostility & 14.79 & 4.646 & 100 \\
\hline \multicolumn{3}{c}{ Table 6. Descriptive Statistics } \\
\hline
\end{tabular}

\begin{tabular}{|c|c|c|c|c|c|c|}
\hline \multicolumn{7}{|c|}{ Correlations } \\
\hline & & SADQ & AGG PHY & AGG Verbal & Anger & Hostility \\
\hline \multirow{3}{*}{ SADQ } & $\begin{array}{l}\text { Pearson } \\
\text { correlation }\end{array}$ & 1 & $.490^{* *}$ & $.435^{* *}$ & $.409^{* *}$ & $.256^{*}$ \\
\hline & sig. (2-tailed) & & .000 & .000 & .000 & .010 \\
\hline & $\mathrm{N}$ & 100 & 100 & 100 & 100 & 100 \\
\hline \multirow{3}{*}{$\begin{array}{l}\text { AGG } \\
\text { physical }\end{array}$} & $\begin{array}{l}\text { Pearson } \\
\text { correlation }\end{array}$ & $.490^{*}$ & 1 & $.435^{*}$ & $.348^{* *}$ & $.260^{* *}$ \\
\hline & sig. (2-tailed) & .000 & & .000 & .000 & .009 \\
\hline & $\mathrm{N}$ & 100 & 100 & 100 & 100 & 100 \\
\hline \multirow{3}{*}{$\begin{array}{c}\mathrm{AGG} \\
\text { verbal }\end{array}$} & $\begin{array}{c}\text { Pearson } \\
\text { correlation }\end{array}$ & $.435^{* *}$ & $.435^{* *}$ & 1 & $.341^{* *}$ & 053 \\
\hline & sig. (2-tailed) & .000 & .000 & & .001 & .602 \\
\hline & $\mathrm{N}$ & 100 & 100 & 100 & 100 & 100 \\
\hline \multirow{3}{*}{ Anger } & $\begin{array}{l}\text { Pearson } \\
\text { correlation }\end{array}$ & $.409^{*}$ & $.348^{* *}$ & $.341^{*}$ & 1 & $.310^{* *}$ \\
\hline & sig. (2-tailed) & .000 & .000 & .001 & & .002 \\
\hline & $\mathrm{N}$ & 100 & 100 & 100 & 100 & 100 \\
\hline \multirow{3}{*}{ Hostility } & $\begin{array}{l}\text { Pearson } \\
\text { correlation }\end{array}$ & $.256^{*}$ & $.260^{* *}$ & .053 & $.310^{* *}$ & 1 \\
\hline & sig. (2-tailed) & .010 & .009 & .602 & .002 & \\
\hline & $\mathrm{N}$ & 100 & 100 & 100 & 100 & 100 \\
\hline
\end{tabular}

\begin{tabular}{|c|c|c|c|c|c|c|}
\hline & & $\begin{array}{l}\text { Sum of } \\
\text { Squares }\end{array}$ & df & $\begin{array}{c}\text { Mean } \\
\text { Square }\end{array}$ & $\mathbf{F}$ & Sig. \\
\hline \multirow{3}{*}{ Age } & Between groups & 14.152 & 2 & 7.076 & .112 & .895 \\
\hline & Within groups & 6150.408 & 97 & 63.406 & & \\
\hline & Total & 6164.560 & 99 & & & \\
\hline \multirow{3}{*}{$\begin{array}{l}\text { Age of onset } \\
\text { of illness }\end{array}$} & Between groups & 42.097 & 2 & 21.048 & .708 & .495 \\
\hline & Within groups & 2882.863 & 97 & 29.720 & & \\
\hline & Total & 2924.960 & 99 & & & \\
\hline \multirow{3}{*}{ Last intake } & Between groups & 8. 298 & 2 & 4.149 & 1. 264 & .287 \\
\hline & Within groups & 318.292 & 97 & 3.281 & & \\
\hline & Total & 326.590 & 99 & & & \\
\hline \multirow{3}{*}{$\begin{array}{l}\text { Number of } \\
\text { hospital } \\
\text { admission }\end{array}$} & Between groups & 1.201 & 2 & .600 & .608 & .547 \\
\hline & Within groups & 95.789 & 97 & .988 & & \\
\hline & Total & 96.990 & 99 & & & \\
\hline \multirow{3}{*}{$\begin{array}{l}\text { Abstinence } \\
\text { duration }\end{array}$} & Between groups & 9.443 & 2 & 4.721 & 277 & .759 \\
\hline & Within groups & 1655.317 & 97 & 17. 065 & & \\
\hline & Total & 1664.760 & 99 & & & \\
\hline \multirow{3}{*}{$\begin{array}{l}\text { Number of } \\
\text { relapse }\end{array}$} & Between groups & 4.966 & 2 & 2.483 & .975 & .381 \\
\hline & Within groups & 247. 034 & 97 & 2.547 & & \\
\hline & Total & 252.000 & 99 & & & \\
\hline \multicolumn{7}{|c|}{$\begin{array}{c}\text { Table 8. Comparison of Means of Illness Variables } \\
\text { within Groups: ANOVA }\end{array}$} \\
\hline
\end{tabular}

\section{DISCUSSION}

In our study, the sociodemographic profile shows that middle age men with strong family history (75 \%) of alcoholism who were married and living in joint family came earlier to hospitals for treatment, possibly due to good social support, at least initially. But more men relapsed within three months of duration, probably due to increasing caregiver burden. While considering these, strengthening our global intervention programme with earlier psychosocial interventions will help us to prevent earlier relapses as these. Occupation wise, more people were either unskilled (31) or semiskilled (30), than unemployed (23); literacy rate does not show much variation, hence the individuals may benefit with intensive cognitive behavioural therapy in addition to conventional treatment.

Coming to abstinence, violating individuals had deficits in attentional, planning and motor sub facets indicating their impulsive nature playing a major role in quick return to lapse. In addition, the behavioural disinhibition in the form of aggression appears to be a problematic threat to their caregivers as well as their own life. It is responsible for socially deviant behaviour, and it represents a clinical challenge for mental healthcare providers. This is due to their defective social problem-solving nature which is supported by many studies. $^{25,26,27}$ Alcohol dependent subjects with a history of suicidal behaviour show a profile with higher impulsive and aggressive behaviour and a significantly higher rate of depressive disorders and a low serotonin level. The latter could be significantly modified by using antidepressants during the course of treatment in these individuals along with non-pharmacological methods. It is also useful in other impulsivity-related psychopathological conditions. Newer drugs targeting symptoms and complications associated with alcohol included in a deaddiction protocol create tremendous improvement and aid the individual to come out of the clutches of dependence more easily. ${ }^{28}$

Literature showing individuals with neurodevelopmental conditions such as attention deficit hyperactivity disorder (ADHD) having higher rates of developing substance abuse disorders as adults offers a number of potential explanations for the relationship between impulsivity and alcohol use or substance abuse. Disruptive behaviour, particularly conduct disorder, typically precede the initiation of use of a variety of substances that, in turn, precede the diagnosis of alcohol dependence in adolescents. ${ }^{36}$

Depressive symptoms as well as high level of impulsivity are subjects of special interest in alcohol dependence because negative emotional feeling such as anxiety, low mood, anger, hostility, chronic sense of boredom are the factors considered to influence the course of this disorder. ${ }^{37}$ Even though both have a common factor in serotonin level, until now mutual relationships between impulsivity and depression have not been investigated thoroughly in alcohol-dependent patients. ${ }^{38}$ Research performed during the past 20 years had established the relationship of serotonin (5-hydroxy tryptamine, 5-HT) neurotransmission to alcohol dependence. Neural circuitry in obsessive drinking pattern directs us to understand it as an important neurochemical transmission here, and significant evaluation of this could help us to employ appropriate coping strategies, stimulus control and urge management techniques in relapse prevention.

First order factors of impulsivity (non-planning and motor) dominated the correlation between alcohol dependence and physical aggression in our study. These data suggests that impulsivity marked by lack of self-control and cognitive complexity (non-planning), and the poor behavioural control and perseverance (motor) partially accounts for elevated levels of aggression observed in chronic drinking men. ${ }^{41}$ The construct of both the scales of impulsivity and aggression proved to be an appropriate and effective tool to understand the behaviour and disease models of alcoholism, and can be more useful in the treatment programme.

\section{CONCLUSIONS}

This study describes the important role of behavioural model and disease model of alcoholism. ${ }^{42,43}$ There are higher levels of interlinking between alcohol dependence with biological and behavioural indicators of impulsivity and aggression, and greatly impacts on the ability to control the quantity and frequency of the drinking behaviour. The results support that 
relapse is an acquired behaviour, modification of which can help control the substance taking pattern through adequate cognitive behavioural techniques in addition to pharmacological treatment. The authors suggest that more researches are needed to focus on causality and intervention. ${ }^{44}$

\section{Limitations of the Study}

- The study was conducted in tertiary care hospital; it is not representative of the total population, hence, could not be generalized to the community levels.

- Personality factors were not excluded, at the same time not inclusively used in this study.

\section{Future Direction}

1. Genetic studies to explore biological marker especially related to impulsivity and aggression sub facet and its transmission required for more understanding.

2. Longitudinal study with further follow up at periodic intervals will show better results. $49,50,51$

3. Early life stress (ELS) leads to increased susceptibility, 52 needs more research to establish multiple connectivity and causality in this field.

Data sharing statement provided by the authors is available with the full text of this article at jemds.com.

Financial or other competing interests: None.

Disclosure forms provided by the authors are available with the full text of this article at jemds.com.

\section{REFERENCES}

[1] Lejuez CW, Magidson JF, Mitchell SH, et al. Behavioral and biological indicators of impulsivity in the development of alcohol use, problems and disorders. Alcoholism: Clinical and Experimental Research 2010;34(8):1334-45.

[2] Heinz AJ, Beck A, Meyer-Lindenberg A, et al. Cognitive and neurobiological mechanisms of alcohol-related aggression. Nature Reviews Neuroscience 2011;12(7):400-13.

[3] Jakubczyk A, Wrzosek M, Łukaszkiewicz J, et al. The CC genotype in HTR2A T102C polymorphism is associated with behavioral impulsivity in alcohol-dependent patients. Journal of Psychiatric Research 2012;46(1):449.

[4] Conner KR, Swogger MT, Houston RJ. A test of the reactive aggression-suicidal behavior hypothesis: is there a case for proactive aggression? Journal of Abnormal Psychology 2009;118(1):235.

[5] Tikkanen R, Sjöberg RL, Ducci F, et al. Effects of MAOAgenotype, alcohol consumption and aging on violent behavior. Alcoholism: Clinical and Experimental Research 2009;33(3):428-34.

[6] Zupanc T, Pregelj P, Tomori M, et al. TPH2 polymorphisms and alcohol-related suicide. Neuroscience letters 2011;490(1):78-81.

[7] Tobore TO. On the neurobiological role of oxidative stress in alcohol-induced impulsive aggressive and suicidal behavior. Substance Use \& Misuse 2019;54(14):2290303.
[8] Preuss UW, Koller G, Bondy B, et al. Impulsive traits and 5-HT2A receptor promoter polymorphism in alcohol dependents: possible association but no influence of personality disorders. Neuropsychobiology 2001;43(3):186-91.

[9] Gerald MS, Higley JD. Evolutionary underpinnings of excessive alcohol consumption. Addiction 2002;97(4):415-25.

[10] Beck A, Schlagenhauf F, Wüstenberg T, et al. Ventral striatal activation during reward anticipation correlates with impulsivity in alcoholics. Biological Psychiatry 2009;66(8):734-42.

[11] Beck A, Schlagenhauf F, Wüstenberg T, et al. Ventral striatal activation during reward anticipation correlates with impulsivity in alcoholics. Biological Psychiatry 2009;66(8):734-42.

[12] Hallikainen T, Saito T, Lachman HM, et al. Association between low activity serotonin transporter promoter genotype and early onset alcoholism with habitual impulsive violent behavior. Molecular Psychiatry 1999;4(4):385-8.

[13] Enoch MA, Goldman D. The genetics of alcoholism and alcohol abuse. Current Psychiatry Reports 2001;3(2):144-51.

[14] Verdejo-García A, Bechara A, Recknor EC, et al. Negative emotion-driven impulsivity predicts substance dependence problems. Drug and Alcohol Dependence 2007;91(2-3):213-9.

[15] Pinto E, Reggers J, Gorwood P, et al. The short allele of the serotonin transporter promoter polymorphism influences relapse in alcohol dependence. Alcohol \& Alcoholism 2008;43(4):398-400.

[16] Jakubczyk A, Klimkiewicz A, Wnorowska A, et al. Impulsivity, risky behaviors and accidents in alcoholdependent patients. Accident Analysis \& Prevention 2013;51:150-5.

[17] Kose S, Steinberg JL, Moeller FG, et al. Neural correlates of impulsive aggressive behavior in subjects with a history of alcohol dependence. Behavioral Neuroscience 2015;129(2):183-96.

[18] Single E, Rehm J, Robson L, et al. The costs of substance abuse in Canada, Ottawa: Canadian Centre on Substance Abuse, 1996: p. 532.

[19] Health and Welfare Canada. Alcohol and other drug use by Canadians: a national alcohol and other drug survey (1989) technical report. Ottawa: Health and welfare Canada, 1992.

[20] McLellan AT, Lewis DC, O'brien CP, et al. Drug dependence, a chronic medical illness: implications for treatment, insurance, and outcomes evaluation. JAMA 2000;284(13):1689-95.

[21] McGirr A, Paris J, Lesage A, et al. Risk factors for suicide completion in borderline personality disorder: a casecontrol study of cluster B comorbidity and impulsive aggression. Journal of Clinical Psychiatry 2007;68(5):721-9.

[22] McMurran M, Egan V, Blair M, et al. The relationship between social problem-solving and personality in mentally disorder offenders. Personality and Individual Differences 2001;30(3):517-24.

[23] Collin JJ. Drinking and violence: an individual offenders focus. In: Martin SE, edr. Alcohol and interpersonal 
violence: fostering multidisciplinary perspectives. USA: NIH Publication 1993: p. 221-36.

[24] Lipsey MW, Wilson DB, Cohen MA, et al. Is there a causal relationship between alcohol use and violence? A synthesis of evidence. In: Galanter $M$, edr. Recent developments in alcoholism: alcohol and violence. Vol. 13. New York: Plenum Press 1997: p. 245-82.

[25] Pattron JH, Stanford MS, Barratt ES. Factor structure of the barrett impulsiveness scale. Journal of Clinical Psychology 1995;51(6):768-74.

[26] Moeller EG, Barratt ES, Dougherty DM, et al. Psychiatric aspects of impulsivity. American Journal of Psychiatry 2001;158(11):1783-93.

[27] Moeller FG, Dougherty DM. Antisocial personality disorder, alcohol and aggression. Alcohol Research and Health 2001;25(1):5-11.

[28] Brady KT, Myrick H, Henderson S, et al. The use of divalproex in alcohol relapse prevention: a pilot study. Drug and Alcohol Dependence 2002;67(3):323-30.

[29] Koller G, Preuss UW, Bottlender M, et al. Impulsivity and aggression as predictors of suicide attempts in alcoholics. European Archives of Psychiatry and Clinical Neuroscience 2002;252(4):155-60.

[30] Soloff PH, Lynch KG, Moss HB. Serotonin, impulsivity and alcohol use disorders in the older adolescent: a psychobiological study. Alcoholism: Clinical and Experimental Research 2000;24(11):1609-19.

[31] Brent DA, Mann JJ. Familial pathways to suicidal behaviorunderstanding and preventing suicide among adolescents. New England Journal of Medicine 2006;355(26):2719-21.

[32] Benegal V, Antony G, Venkatasubramanian G, et al. Imaging study: gray matter volume abnormalities and externalizing symptoms in subjects at high risk for alcohol dependence. Addiction Biology 2007;12(1):122-32.

[33] Moeller FG, Dougherty DM, Barratt ES, et al. Increased impulsivity in cocaine dependent subjects independent of antisocial personality disorder and aggression. Drug and Alcohol Dependence 2002;68(1):105-111.

[34] Moeller FG, Dougherty DM. Impulsivity and substance abuse: What is the connection? Addictive Disorders \& Their Treatment 2002;1(1):3-10.

[35] Allen TJ, Moeller FG, Rhoades HM, et al. Impulsivity and history of drug dependence. Drug and Alcohol Dependence 1998;50(2):137-45.

[36] Kuperman S, Schlosser SS, Kramer JR, et al. Developmental sequence from disruptive behavior diagnosis to adolescent alcohol dependence. American Journal of Psychiatry 2001;158(12):2022-6.

[37] Strac DS, Erjavec GN, Perkovic MN, et al. Association of GABAA receptor $\alpha 2$ subunit gene (GABRA2) with alcohol dependence-related aggressive behavior. Progress in Neuropsychopharmacology and Biological Psychiatry 2015;63:119-25.

[38] Jakubczyk A, Klimkiewicz A, Topolewska-Wochowska A, et al. Relationships of impulsiveness and depressive symptoms in alcohol dependence. Journal of Affective Disorders 2012;136(3):841-7.

[39] Pettinati HM, Kranzler HR, Madaras J. The status of serotonin-selective pharmacotherapy in the treatment of alcohol dependence. Recent Developments in Alcoholism 2003;16:247-62.

[40] Contini V, Marques FZC, Garcia CED, et al. MAOA-uVNTR polymorphism in a Brazilian sample: further support for the association with impulsive behaviors and alcohol dependence. American Journal of Medical Genetics Part B: Neuropsychiatric Genetics 2006;141B(3):305-8.

[41] Parrott DJ, Giancola PR. Alcohol dependence and physical aggression: The mediating effect of dispositional impulsivity. Journal of Drug Addiction, Education and Eradication 2011;7(4):315-32.

[42] Naqvi NH, Ochsner KN, Kober H, et al. Cognitive regulation of craving in alcohol-dependent and social drinkers. Alcoholism: Clinical and Experimental Research 2015;39(2):343-9.

[43] Courtney KE, Arellano R, Barkley-Levenson E, et al. The relationship between measures of impulsivity and alcohol misuse: an integrative structural equation modeling approach. Alcoholism: Clinical and Experimental Research 2012;36(6):923-31.

[44] Marlatt GA. Taxonomy of high risk situations for alcohol relapse: evoluation and development of a cognitive behavior model. Addiction 1996; (Suppl 91):S37-49.

[45] Kang JI, Hwang SS, Choi JR, et al. Telomere length in alcohol dependence: a role for impulsive choice and childhood maltreatment. Psychoneuroendocrinology 2017;83:72-8.

[46] Wojnar M, Brower KJ, Strobbe S, et al. Association between Val66Met brain-derived neurotrophic factor (BDNF) gene polymorphism and post-treatment relapse in alcohol dependence. Alcoholism: Clinical and Experimental Research 2009;33(4):693-702.

[47] Gullo MJ, John NS, Young RM, et al. Impulsivity-related cognition in alcohol dependence: Is it moderated by DRD2/ANKK1 gene status and executive dysfunction? Addictive Behaviors 2014;39(11):1663-9.

[48] Gilpin NW, Koob GF. Neurobiology of alcohol dependence: focus on motivational mechanisms. Alcohol Research \& Health 2008;31(3):185-95.

[49] Poikolainen K. Risk factors for alcohol dependence: a questionnaire survey. Alcoholism: Clinical and Experimental Research 1997;21(6):957-61.

[50] King SM, Keyes M, Malone SM, et al. Parental alcohol dependence and the transmission of adolescent behavioral disinhibition: a study of adoptive and nonadoptive families. Addiction 2009;104(4):578-86.

[51] Gullo MJ, Irvine K, Feeney GF, et al. Short message service (SMS) reminders improve treatment attendance in alcohol dependence, but are less effective for patients high in impulsivity. Addictive Behaviors 2018;87:97-100.

[52] Kim ST, Hwang SS, Kim HW, et al. Multidimensional impulsivity as a mediator of early life stress and alcohol dependence. Scientific Reports 2018;8(1):1-9. 